\title{
Buddhism and Abortion: A Western Approach
}

in Buddhism and Abortion. Editor: Damien Keown. 1998.

by James Hughes

\section{I ntroduction}

I once believed it important to determine the "Buddhist view" on many social and political questions. Today I'm much more circumspect. Buddhist texts offer few coherent views outside of the core doctrinal elements. Consequently, Buddhists, to an even greater degree than most religionists, are required to address contemporary problems in the spirit of their teachings, rather than according to the letter of their law.

In the case of abortion, classical Buddhist texts, from the Pali canon through the Mahayana sutras, offer no specific guidance. Even if there was a specific, classical Buddhist text addressing the moral status of the fetus and the act of abortion, it would not be consistent with "Buddhism” to accept this teaching uncritically. Buddhism encodes with its teachings a reflexive, dynamic, self-critical element, beginning with the Kalama Sutra, which encourages Buddhists not to simply follow scriptures, but to continually adapt the Dharma to new audiences.

Consequently, a Buddhist approach to abortion has more to do with approaching the issue with a characteristic set of concerns, and in dialogue with a vast body of texts and teachers. It therefore comes as little surprise that most Western and Japanese Buddhists come away believing in the permissibility of abortion, while many other Buddhists believe abortion to be murder. In this essay I would like to sketch some of the reasons why most Western Buddhists accept abortion as an unfortunate but necessary part of women's reproductive health care.

\section{Buddhism and Reproduction}

First, it is important to note that Buddhism, unlike many other religions, does not hold that humans have a responsibility to procreate, and forbids the consecration of marriage or birth by Buddhist monks and nuns. The religions most opposed to abortion, notably Catholicism, believe that sex is for procreation, and that procreation is a duty and gift from God. In these theistic traditions, an abortion is an usurpation of God's will.[1]

In Buddhism however, the monastic life is of a higher order than the householder life. Unlike the pro-procreative religions, in Buddhism masturbation and homosexuality were seen as morally equivalent to heterosexuality.[2] One entire book of the Pali canon, the Therigatha, is devoted to the description of the misfortunes of maidens, married women and mothers, and the joyous liberation they discovered in the nuns" order. This radical indifference to family life was one of the principal sources of Confucian hostility to Buddhism in China.[3] The late Trevor Ling[4] pointed out that the Sinhalese embrace of contraception and abortion was so enthusiastic in the 1960s, compared to Sri Lanka”s Muslims, Catholics and Hindus, that racialist monks began to argue, with little success, that Buddhists had an obligation to "race-religion-nation" to reproduce.

In itself, a denigration of sexuality and reproduction does not lead to the condoning of abortion, and these attitudes do not explain Western Buddhists” views on abortion. On the contrary, Western Buddhists have been drawn to the strains of Buddhism more tolerant of sexuality, principally Japanese Buddhism and Tibetan Tantra.[5] Even Western Theravadan communities tend to de-emphasize anti-carnality. [6]

Of course, in Asia and in Asian Buddhist immigrant communities in the West, monks often do officiate in marriages and birth blessings, and Buddhism has developed a "pro-family" lay theology. In these communities 


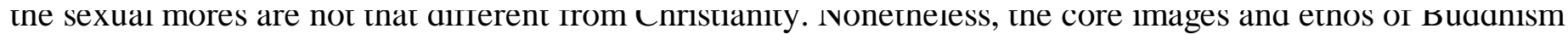
do not sacralize family and reproduction, and this in itself is probably part of the attraction for Western counterculture Buddhists, and part of the explanation of our attitudes towards abortion.

\section{Buddhist Ethics of Abortion}

Buddhists in Asia and in the West have adopted many different moral logics.[7] All of these logics can be used to argue both for and against the permissibility of abortion. Some are more consistent with the textual and historical record of Buddhism, but authentic Buddhist ethicists could hold any of these positions.

For instance, the most simple-minded approach to morality is the letter of the law, and one of the top five precepts of the Buddhist is not to kill. Asserts one American Theravadan Buddhist:

Abortion is the intentional taking of human life, an extremely bad and unwholesome act which is not to be done. For the devout, traditional Buddhist, that is the end of the matter.[8]

Similarly, David Stott, the British student of Tibetan Buddhism asserts:

The performance of abortion or fatality-causing experiments on the unborn child constitute the taking of life, just as surely as the taking of life at any other point in the continuum of conception to death...[9]

While it may sound like sophistry, the question that this precept leaves unanswered is whether an embryo or fetus is alive. While there was a minority tradition in classical Hindu embryology that held that incarnation does not occur till as late as the seventh month,[10] most Buddhist commentators have adopted classical Hindu teachings that the transmigration of consciousness occurs at conception, and therefore that all abortion incurs the karmic burden of killing. Before modern embryology, however, in both Buddhist countries and the West,[11] ideas about conception were scientifically inaccurate, and often associated the beginning of life with events in the third or fourth month of pregnancy. The medieval descriptions of the incarnation of the skandhas in the fetal body do not discuss the fusing of sperm and egg, the growth of a central nervous system and so on.[12] Therefore, not only do their writings lack canonical weight, but they lack convincing relevance.

Another problem in early Buddhists” embryology is their assumption that the transmigration of consciousness is sudden rather than gradual. Based on the findings of modern neuro-embryology, Buddhists today might maintain that the fetus does not fully embody all five skandhas (the "aggregates”, or factors of individuality) and the illusion of personhood until after birth. Gradual embodiment of personhood is the argument developed by most Western ethicists to defend abortion.[13] If the fetus is not yet a fully embodied person, then the karmic consequences of abortion would be even less than the killing of animals, which Buddhism clearly teaches do have moral status. This neurological interpretation of the skandhas may be more consistent with Western Buddhism, which often sees the doctrine of rebirth as peripheral or interprets rebirth metaphorically rather than literally.[14]

Another popular, and probably the dominant, interpretation of Buddhist ethics in the West is utilitarian; [15] that the Buddhist should seek the greatest happiness for the greatest number. Under a utilitarian ethics, a particular abortion, and legal abortion in general, can be ethical so long as the suffering of all beings is lessened. The factors that a utilitarian Buddhist would take into account are the relative amounts of suffering experienced by mothers of unwanted children versus women who have abortions; the suffering of unwanted children versus the "suffering" experienced by a fetus during abortion; the suffering of societies that permit abortion, versus the suffering of societies that don't. Utilitarian Buddhists would consider abortions more moral if the child will be disabled, or lead a painful, unhappy life for some other reason such as poverty; if the mother's life or health is endangered; and if the society or world is threatened by over-population or famine. In a consequentialist, utilitarian ethics, abortion may be ethical in some cases and not others, and for some 
societies and not others.

As critics are quick to point out, utilitarianism can legitimate many repugnant actions, murder among them, and most utilitarians add two modifications to address this "yuck factor": general rules of thumb and a hierarchy of happiness. Since the estimation of the consequences of every action is impossible, most utilitarians accept general principles that will lead to greater happiness in the long run, among them freedom of speech, "a right to life," and so on. For these rule utilitarians, the abortion question returns to whether a fetus is a moral person with a right to life, or more precisely, whether suffering will be less if we treat fetuses as moral persons. Even if the fetus is not a person, permitting abortion may create a cognitive slippery slope to the murder of infants, and then mentally disabled children, and then adults. On the other hand, if clear and defensible distinctions can be made between fetuses and other human life, then it makes more sense to have two separate rules to apply to them.

This clear, defensible line is derived, I believe, from the second utilitarian caveat, the hierarchy of pleasures. This refinement of utilitarianism was articulated by John Stuart Mill in reaction to Bentham's version of utilitarianism which held that a life spent in an opiated stupor was just as moral as a life spent in creative endeavor. Instead, Mill posited the very Buddhist idea that there were higher states of mind which should be factored into any utilitarian calculus as more important than simple pleasures. To the extent that the fetal nervous system exists at all, its "sufferings” and "pleasures” are clearly of a rudimentary order compared to those of the pregnant woman. In other words, the suffering experienced by a self-conscious child when murdered is qualitatively different from that experienced by an infant when aborted, and thus the first can and should be forbidden, while the latter may be acceptable.[16] In reference to the slippery slope argument, LaFleur notes:

The Japanese history of abortion offers an example of moral practices going the other way. In the seventeenth and eighteenth centuries, the Japanese practiced birth control almost entirely through infanticide, when there was no other real option. In the twentieth century, the Japanese have virtually eliminated infanticide, substituting it with abortion. Now, more and more, abortion is being supplanted by contraception.[17]

Within both modern Buddhist ethics and Western bioethics the "sentience" of a being is considered in evaluating the morality of ending it's life; not all life is equal and therefore not all killing is equal. Most Western bioethicists believe that human beings and animals take on ethical significance, a "right to life," to the extent that they are "persons." Some Western ethicists[18] would set a standard which would exclude almost all animals, newborns, and the severely retarded or demented. When they specify which elements of sentience and neurological integrity create the illusion of personhood, Western bioethicists begin to sound remarkably Buddhistic: "the awareness of the difference between self and other; the ability to be conscious of oneself over time; the ability to engage in purposive actions”.[19]

Buddhist psychological analysis is consistent with an ethical distinction between three kinds of beings: those that do not feel pain, those that feel pain, and those with individuated consciousness, i.e. "persons." The insensate are considered by almost all Western philosophers, except the "deep ecologists," some of whom are also Buddhists[20], and the Catholics, to be morally inconsequential. The deep ecologists would extend a right to life to viruses, plants and eco-systems, while the Catholics would extend it to the embryo.

The significance of pain is more universally recognized, leading to the establishment of organizations and laws protecting animals from unnecessary cruelty as domestic pets or in research. Similarly, pediatricians have become increasingly sensitive to the sensitivities of infants receiving shots or circumcision. Buddhism and bioethics would clearly argue for respecting the extent to which the fetus is sensate in the carrying out of abortion, though the end is obviously quick.

The moral significance of murder, however, comes with the development of the illusion of self some time after birth. A Buddhist ethics that tied the significance of killing to the sentience of the being would, in turn,

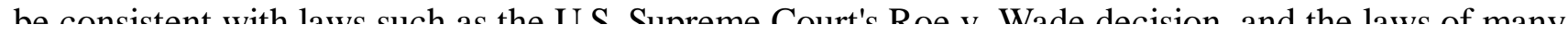


European nations, which allow unrestricted abortion in the first trimester of a pregnancy and more restricted abortion rights in latter stages of pregnancy.

A third ethical logic, and the one argued for by Damien Keown,[21] is a virtue-ethics interpretation of Buddhism. Virtue-oriented Buddhists view the intentions and psychological state of the actor as determining the morality, and karmic consequences, of an act. In this case the mental attitude and motivations of the pregnant woman and her collaborators would determine the ethics of an abortion.

Along this line, Tworkov[22] argues that the karmic skillfulness of an abortion is related to whether the woman became pregnant and made her decision to abort with serious mindfulness. From this perspective, aborting a fetus conceived without an effort at contraception or without serious moral reflection would be more karmically significant, in fact a breaking of the precept against sexual misconduct, than an abortion necessitated in spite of contraception, and undertaken without moral reflection. Tworkov argues that while hardening the heart against fetal life may appear to make the abortion choice easier, in the long run it is important to keep an open heart to the painfulness of the choice. Similarly, in her description of an abortion after she began practicing Zen Buddhism, Margot Milliken says:

A wise friend encouraged me to love this new being, accept it for what it was, send it loving thoughts, and if I decided to have the abortion, to also wish the being a peaceful journey. The other advice was to send myself healing and loving thoughts, and to be completely accepting of the many reactions and feelings I was experiencing. Finally I reached a point of balance and understanding. I had the abortion, and now, four years later, I still have questions. My questions are not about whether I did the right thing; I”m sure I did.[23]

In fact, I believe that most Western Buddhists employ both utilitarian and virtue ethics, in the paradoxical unity of compassion and wisdom. On the one hand, our personal karmic clarity is most related to our cultivation of compassionate intention, but on the other hand we also need to develop penetrating insight into the most effective means to the ends. We do not believe that the person who helps others without any intention of doing so to have accrued merit, while we look upon the person who causes others suffering with the best intentions a hapless fool. Similarly, in approaching the abortion decision, both the mindset of the actors and the utilitarian consequences are important.

\section{The Difference Between Social Ethics and Personal Ethics}

This distinction between the personal karmic consequences of abortion, and the general social consequences, are yet another cause of Western Buddhists tolerance toward abortion. While many Buddhists feel conflict about the moral status of the act for themselves, they fear dire consequences for women and society if abortion were to be re-criminalized. These concerns are in line with those of liberal democracy, but they are also unwittingly in line with a Buddhist traditional of a liberal state.[24]

Western Buddhists are only slowly becoming aware of the social and political ethics of the Buddhist canon. The early Pali canon's image of traditional monarchs was of arrogant egotists pursuing imperialistic, unjust policies, guided solely by greed, hatred and ignorance. When Siddhartha Gautama was born it was predicted that he would either be a world-conqueror or a world-saviour, in line with the Great Man mythos. Though his father tried to steer him toward conquest of the world, Siddhartha conquered himself instead. The symbol of secular power was the wheel of the war chariot, "the wheel of power," but the symbol of the Buddha's awakening was "the wheel of Truth” (dharmachakra) of which he was the "wheel-turner” (chakravartin).

Subsequently Buddhists found that radical disjuncture between dharma and power untenable, and a concept of the righteous king developed. If the king could be converted and brought under the sway of the Sangha, he could be taught to rule with compassion, selflessness and wisdom. Such a qualitatively transformed monarch was called a dharmaraia, or dharma-king. Bv subordinating himself to the wav of truth, the dharmaraia 
allows the dharmachakra to turn the wheel ơ power. A dharmaraja, as portrayed most significantly in the The Lion Roar of the Wheel-Turning Monarch Sutra, provides for all the people and animals of the realm, listens to the counsel of the wise, controls his passions, and most importantly, makes sure that there is no poverty in his kingdom. The first Buddhist emperor, Asoka, attempted to fulfill these obligations of righteous governance by setting out edicts on stone posts throughout India, proclaiming social welfare measures, amnesty for sacrificial animals and encouragement for lay people to practice meditation.[25]

While the dharmaraja/Asoka tradition has inspired many Buddhists to take an active role as a moral force in governance, this model is also one of tolerance. The dharmaraja texts and Asoka himself were tolerant and respectful of non-Buddhist religious groups. The Vajjian Sutra suggests in fact that the support and free movement of religious mendicants of all kinds is a precondition for social health. Internally, the Buddhist order was not to establish a "true” faith, but to simply to schism when major disagreements developed.

Asian Buddhists have often shown a less tolerant side when Buddhism was made the state religion, Western Buddhists have evinced no interest in evangelism or the institutionalization of Buddhist moral edicts as state policy.[26] In other words, the Western liberal moral stance that "I personally disagree with abortion, but I believe it should be legal," is a common stance among Western Buddhists as well, and is consistent with the general moral tolerance of Buddhist governance.[27] Again in the words of Margot Milliken:

Given the present political and social climate, we are in danger of losing the legal right to choose abortion. While I do not believe abortion is something that should be legislated against, I do feel it is an option that should not be taken lightly. Even if it seems that the best choice is to terminate a pregnancy, we must acknowledge we are ending a potential life. This seems more honest than acting as if our "pro-choice" stance does not involve taking life, even though we may assume that that life is not fully realized, conscious or developed.[28]

And in a pamphlet from the Japanese-American Buddhist Churches of America:

It is the woman carrying the fetus, and no one else, who must in the end make this most difficult decision and live with it for the rest of her life. As Buddhists, we can only encourage her to make a decision that is both thoughtful and compassionate.[29]

This stance has its limits. Few Buddhists would say “I”m personally opposed to slavery and torture, but I think they should be legal.” That many Buddhists are politically tolerant of abortion despite personal reservations suggests their recognition that their discomfort with abortion is not a fundamental moral objection, as with slavery or torture, but a personal and emotional one. In most Buddhist societies the occupation of butcher is considered unclean, but no Buddhist society has ever imprisoned or executed butchers. In Buddhist law as well as ethics, abortion is more of the status of killing animals, a matter of personal karmic consequences not state-imposed punishment.

It is certainly possible for a Buddhist to legitimate authoritarian and non-democratic forms of government, and many have, especially in the 20th century in reaction to, and in support of, communism. In the West, however, this Buddhist spirit of tolerance has entered into dialogue with the liberal democratic tradition to develop an model of enlightened citizenship in some Buddhist groups. The liberal democratic model of citizenship, consistent with Buddhism, implies that the citizen's of a society will develop the greater wisdom and insight when they have the freedom to make mistakes.

\section{Acknowledging the Sadness of the Choice}

What happens to the consciousness of a baby that is aborted, or dies very young? What can the parents do to help the baby? Dilgo Khyentse Rinpoche explained: 
The consciousness of those who die before birth, at birth, or in infancy will travel once again through the bardo states, and take on another existence. The same meritorious practices and actions can be done for them as are usually performed for the dead: the purification practice and mantra recitation of Vajrasattva, offering of lights, purification of the ashes, and so on.

In the case of an abortion, in addition to these usual practices, if the parents feel remorse they can help by acknowledging it, asking for forgiveness, and performing ardently the purification practice of Vajrasattva. They can also offer lights, and save lives, or help others, or sponsor some humanitarian or spiritual project, dedicating it to the well-being and future enlightenment of the baby's consciousness.[30]

Despite Sogyal Rinpoche's recent and welcome suggestion, Japan is apparently the only society in the world that has developed a ritual, the mizuko kuyo, for the blessing of the aborted fetuses spirit, and the expiation of the guilt of the reluctant parents. The mizuko kuyo is performed by Buddhist priests, who then place a small statue, a jizo, in the Buddhist cemetery to represent these good wishes. William La Fleur[31] is thus far the principal interpolator of this practice to the West, and he suggests that the practice may be a model for a Western moral approach to abortion.

Robert Aitken Roshi, a successor of the Japanese Zen teacher Yasutani Roshi, took up this challenge in his Hawaiian Zen community, the Diamond Sangha. Adapting and translating the mizuko kuyo ceremony, the Diamond Sangha uses the following ceremony:

The Diamond Sangha Ceremony on the Death of an Unborn Child[32]

1. Three full bows

2. The Three Refuges

3. Enmei Jikku Kannon Gyo or other short sutra in Japanese or English Leader :

We gather today to express our love and support for (names of parents) and to say farewell to a child unborn, a bit of being we have named (name of child), who appeared just as we all do, from the undifferentiated mind, and who passed away after a few moments of flickering life, just as we all do.

In our culture, we place great emphasis upon maintaining life, but truly death is not a fundamental matter, but an incident, another wave. Bassui Zenji speaks of it as clouds fading in the sky. Mind essence, Bassui says, is not subject to birth or death. It is neither being nor nothingness, neither emptiness nor form and color.

It is, as Yamada Koun Roshi has said, infinite emptiness, full of possibilities, at once altogether at rest and also charged with countless tendencies awaiting the fullness of karma. Here (name of child) is in complete repose, at one with the mystery that is our own birth and death, our own no-birth and no-death.

5. Heart Sutra in Japanese and English, as parents, leader, and friends offer incense.

6. Leader:

Buddha nature pervades the whole universe, existing right here and now: 
with our reciting of Enmei Jikku Kannon Gyo

let us unite with

the Ancient Seven Buddhas,

Fully Realized Shakyamuni Buddha,

Great Compassion Avalokiteshvara Bodhisattva,

all Founding Teachers, past, present, future.

We especially dedicate our love and our prayerful thoughts to you (name of child)

May you rest in peace

Let true Dharma continueÑ

Sangha relations become complete

All:

All Buddhas throughout space and time,

all Bodhisattvas, Mahasattvas,

the Great Prajna Paramita.

7. Great Vows for All in English

8. Three full vows

Western Buddhists could make quite a contribution to the abortion conflict by offering these sentiments, reflections and rituals for adaptation by our Christian and secular neighbors.

\section{Bibliography}

Aitken, Robert. 1984. The Mind of Clover: Essays on Zen Buddhist Ethics. San Francisco: North Point Press.

Anonymous. 1986. “Buddhist Views on Abortion,” Spring Wind 6 (1-4).

Anonymous. A Shin Buddhist Stance on Abortion. San Francisco: Buddhist Churches of America.

Batchelor, Stephen. 1992. "Rebirth: A Case for Buddhist Agnosticism,” Tricycle: the Buddhist Review: 15 ग 
$10-<د$.

Bennett, Michael. 1989. "Personhood from a Neuroscientific Perspective.” Pp. 83-86 in Abortion Rights and Fetal Personhood, eds. Ed Doer and James Prescott. Centerline Press.

Brooks, Anne Page. 1981. “Mizuko Kuyo and Japanese Buddhism” Japanese Journal of Religious Studies 8:119-47.

Cabezon, Jose Ignacio, ed. 1991. Buddhism, Sexuality and Gender. SUNY Press.

Chen, Kenneth. 1973. The Chinese Transformation of Buddhism. Princeton, NJ: Princeton University Press

Dhonden, Yeshi. 1980. “Embryology in Tibetan Medicine”, in Tibetan Medicine. Dharamsala: Library of Tibetan Works and Archives.

Eiki, Hoshino and Takeda Dosho. 1987. "Indebtedness and comfort: the undercurrents of mizuko kuyo in contemporary Japan”, Japanese Journal of Religious Studies 14:305-20.

Fletcher, Joseph. 1979. Humanhood: Essays in Biomedical Ethics. Buffalo: Prometheus Books.

Florida, R. 1991. “Buddhist Approaches to Abortion”, Asian Philosophy 1:39-50.

Flower, Michael J. 1985. “Neuromaturation of the human fetus.” Journal of Medicine and Philosophy 10:237-251.

Friedman, Lenore. 1987. Daughters of Lion's Yawn: Women Teachers of Buddhism in America. Boulder, CO: Shambhala.

Gross, Rita M. 1992. Buddhism after Patriarchy: A Feminist History, Analysis and Reconstruction of Buddhism. SUNY.

Hughes, James. 1986. “Buddhist Feminism,” Spring Wind (Toronto): 36-45.

Imamura, Ryo. 1984. “The Shin Buddhist Stance on Abortion,” Buddhist Peace Fellowship Newsletter 6: 6-7.

Jones, Ken. 1989. The Social Face of Buddhism. London: Wisdom.

King, Winston. 1994. “A Buddhist Ethics Without Karmic Rebirth? “ Journal of Buddhist Ethics 1:33-44.

Klein, Anne. 1994. Meeting the Great Bliss Queen: Buddhists, Feminists and the Art of the Self. Boston: Beacon.

Kohlberg, Lawrence. 1981. The Philosophy of Moral Development. New York: Harper and Row.

Kuczewski, Mark G. 1994. “Whose Will Is It Anyway? A Discussion of Advance Directives, Personal Identity and Consensus in Medical Ethics”, Bioethics, 8(1): 27-48.

LaFleur, William R. 1992. Liquid Life: Abortion and Buddhism in Japan. Princeton: Princeton University Press.

1990. "Contestation and Confrontation: The Morality of Abortion in Japan. “ Philosophy East and West 40:529-42.

1995a. "Silences and Censures: Abortion, History, and Buddhism in Japan. A Rejoinder to George Tanabe.” Japanese Journal of Religious Studies 22/1-2:185-196. 
1995b. “The Cult of Jizo: Abortion Practices in Japan and What They Can Teach the West. " Tricycle, Summer : 41-44.

Lecso, Philip A. 1987. “A Buddhist View of Abortion,” Journal of Religion and Health 26:214-18.

Ling, Trevor. 1969. “Buddhist Factors in Population Growth and Control,” Population Studies 23:53-60. 1973. The Buddha. London: Pelican.

8. 1980. “Buddhist Values and Development Problems: A Case Study of Sri Lanka,” World Development,

Lipner, J. J. 1989. “The Classical Hindu View on Abortion and the Moral Status of the Unborn,” in Hindu Ethics, ed. H. G. Coward, J. J. Lipner, and K. K. Young, 41-69. Albany, New York: State University of NewYork Press.

Lizza, John P. 1993. "Persons and death: what's metaphysically wrong with our current statutory definition of death?” Journal of Medicine \& Philosophy 18:351-74.

Luker, Kristin. 1984. Abortion and the Politics of Motherhood. University of California Press.

Milliken, Margot Wallach. 1986. Not Mixing Up Buddhism: Essays on Women and Buddhist Practice. eds. Kahawai Collective. Fredonia, NY: White Pine Press: 74-77.

Nelkin, Dorothy. 1983. “The Politics of Personhood,” Milbank Quarterly 61(1): 101-12.

Pali Text Society, trans. 1980. Therigatha. London: Pali Text Society.

Parfit, Derek. 1984. Reasons and Persons. Oxford University Press.

Parrinder, Geoffrey. 1980. Sex in the World's Religions. London: Sheldon Press.

Seed, John, Joanna Macy, Pat Fleming, Arne Naess. 1988. Thinking Like a Mountain: Towards a Council of All Beings. New Society Publishers.

Smith, Bardwell. 1988. "Buddhism and Abortion in Contemporary Japan: Mizuko Kuy $\ddagger$ and the Confrontation with Death,” Japanese Journal of Religious Studies 15:3-24.

Smithers, Stuart. 1992. “Freedom's just another word,” Tricycle, Fall: 34-39.

Sogyal Rinpoche. 1992. The Tibetan Book of Living and Dying. Harper Collins.

Stott, David. 1985. A Circle of Protection for the Unborn. Bristol: Ganesha Press.

Thurman, Robert. The Politics of Enlightenment. In press.

1992. “The Politics of Enlightenment,” Tricycle, Fall: 28-33.

1988. "Nagarjuna's Guidelines for Buddhist Social Activism”, in F. Eppsteiner, ed. The Path of

Compassion: writings on socially engaged Buddhism. Berkeley: Parallax Press.

Tisdale, Sallie. 1994. “Nothing Special: The Buddhist Sex Quandry,” Tricycle, Winter: 44-48.

Thnlav Mirhaol 1984 Ahnrtinn and Infantirido Ovford I Tnivarcity Drace 
Tworkov, H. 1992. “Anti-abortion/pro-choice: taking both sides.” Tricycle: the Buddhist Review: 60-69.

Werblowsky, Z. (1984) “Mizuko Kuył; Notulae on the most important ÒNew ReligionÓ of Japan,” Japanese Journal of Religious Studies 18, pp. 295-354.

Wheeler, Kate. 1994. "Vinaya Vignettes: or, why the buddha had to make some rules,” Tricycle, Summer: 84-89.

Zwilling, Leonard. 1992. "Homosexuality as seen in Indian Buddhist texts," Buddhism, Sexuality and Gender ed. Jose« Ignacio Cabezon. NY: SUNY Press.

\section{References}

[1] Parrinder, Geoffrey. 1980. Sex in the World's Religions. London: Sheldon Press.

[2] Zwilling, Leonard. 1992. "Homosexuality as seen in Indian Buddhist texts,” Buddhism, Sexuality and Gender ed. Jose« Ignacio Cabezon. NY: SUNY Press. Wheeler, Kate. 1994. "Vinaya Vignettes: or, why the buddha had to make some rules," Tricycle, Summer: 84-89.

[3] Chen, Kenneth. 1973. The Chinese Transformation of Buddhism. Princeton, NJ: Princeton University Press.

[4] Ling, T. 1969. "Buddhist Factors in Population Growth and Control,” Population Studies 23:53-60.

[5] See especially Sallie Tisdale's essay in Tricycle (Winter 1994: 44-48) “Nothing Special: The Buddhist Sex Quandry.”

[6] The principal exception to this appears to be the British Friends of Western Buddhist Order, directed by the British monk Sangharakshita, though even in this case sexuality itself is not seen as problematic, but rather sex roles and behavior patterns.

[7] I refer here to the work of Kohlberg (1981), though the ethical logics I discuss do not correspond to his schema directly.

[8] Leonard Price. 1985. “A Buddhist View of Abortion,” Washington Buddhist 16, 4: 3-13.

[9] Stott, David. 1985. A Circle of Protection for the Unborn. Bristol: Ganesha Press.

[10] Lipner, J. J. 1989. “The Classical Hindu View on Abortion and the Moral Status of the Unborn”, In Hindu Ethics, ed. H. G.

Coward, J. J. Lipner, and K. K. Young, 41-69. Albany, New York: State University of New York Press.

[11] See for instance Luker's 1984 investigation of beliefs about the onset of pregnancy in American history.

[12] For a discussion of traditional Tibetan embryology, see Dhonden, 1980 and Lecso, 1987

[13] See for instance Tooley, 1984; Flower, 1985; Bennett, 1989.

[14] See for instance Batchelor, 1992; King, 1994.

[15] Keown, Damien. 1992. The Nature of Buddhist Ethics. St. Martins Press.

[16] Of course, this raises the question of the painless death, which leads to another rule of thumb, that we"ll all be happier if we know we are protected from murder, no matter how humane our assassins.

[17] LaFleur, 1995b:44.

[18] See for instance Tooley, 1984

[19] See for instance, Fletcher, 1979

[20] See for instance Seed, John, Joanna Macy, Pat Fleming, Arne Naess. 1988. Thinking Like a Mountain: Towards a Council of All Beings. New Society Publishers. 
$\lfloor<1\rfloor$ Keown, $19 y<$.

[22] Tworkov, H. 1992. “Anti-abortion/pro-choice: taking both sides.” Tricycle: the Buddhist Review: 60-69.

[23] Milliken, Margot Wallach. 1986. Not Mixing Up Buddhism: Essays on Women and Buddhist Practice. eds. Kahawai Collective. Fredonia, NY: White Pine Press: 74-77.

[24] My thoughts on Buddhist social and political ethics are drawn largely from Trevor Ling's The Buddha, 1973, London: Pelican.

[25] See especially Robert Thurman's radical interpretation of the ideal Buddhist state (1988).

[26] See Smithers (1992) for an interesting discussion of the historical tension between the precepts and antinomian freedom in Buddhism, and the parallel tension between morality and liberal state in the United States.

[27] See for instance, Imamura, 1984 and Lecso, 1987

[28] Milliken, 1986: 76.

[29] Anonymous. A Shin Buddhist Stance on Abortion. San Francisco: Buddhist Churches of America.

[30] Sogyal Rinpoche. 1992. The Tibetan Book of Living and Dying. Harper Collins: 376.

[31] LaFleur 1990, 1992, 1995a, 1995b.

[32] Aitken, Robert. 1984. The Mind of Clover: Essays on Zen Buddhist Ethics. San Francisco: North Point Press: 22. 